\title{
PERAN TOKOH AGAMA DALAM MEWUJUDKAN KETERATURAN MASYARAKAT
}

\author{
Sulis Rahmawanto \\ Institut Agama Islam Nahdlatul Ulama (IAINU) Kebumen \\ e-mail:sulisrahmawanto@gmail.com
}

\begin{abstract}
Abstrak
Teknologi dan informasi memnerikan peranan penting dalam dunia pendidikan Islam termasuk pesantren. Informasi merupakan satu-satunya sumber yang dibutuhkan seorang pimpinan lembaga pendidikan. Informasi dapat diolah dari sumber lain yang dipengaruhi oleh organisasi yang sangat kompleks dan perangkat komputer yang dimiliki. Informasi dapat memperkuat kineija lembaga pendidikan, layaknya Kinerja usaha lembaga bisnis. Informasi dapat digali melalui sumber-sumber yang tersedia, seperti sumber daya manusia, material, alat, biaya yang dibutuhkan, serta data yang akan diolah. Dalam hal ini, penerapan sistem informasi manajemen pendidikan memiliki kapabilitas dalam mendukung keberhasilan dunia pendidikan saat ini. Beberapa fungsi dan tugas pokok kepemimpinan dalam konteks adalah menyatupadukan orang-orang yang berbeda-beda motivasinya itu dengan motivasi yang sama, mengusahakan suatu kelompok dinamis secara sadar, menciptakan suatu lingkungan dimana terdapat integrasi antara individu dan kelompok dengan lembaga pendidikan, memberikan inspirasi dan mendorong anggota-anggotanya bekerja seefektif mungkin, dan menumbuhkan kesadaran pendidikan yang senantiasa mengalami perubahan yang dinamis dan mengusahakan agar orang-orang yang dipimpinnya itu dapat menyesuaikan dengan perubahan situasi. Artikel ini membahas tentang pola pengembangan tersebut berbasis teknologi, komunikasi, dan informasi.
\end{abstract}

Kata Kunci: kepemimpinan, teknologi, informasi, manajemen, pendidikan Islam 


\section{A. Pendahuluan}

Sekian lama Indonesia merdeka terbebas dari penjajahan bersenjata dari negara lain. Namun demikian masih banyak tugas yang perlu untuk selalu dan selalu diselesaikan. Apa lagi terkait dengan konflik antar agama maupun intern dalam agama itu sendiri. Berbagai masalah atau konflik bermunculan dilingkungan negara Indonesia yang sedikit banyak di sebabkan oleh unsur keagamaan. ${ }^{1} \mathrm{Hal}$ inilah yang menjadikan rasa kemerdekaan bagi masyarakat Indonesia kurang begitu dapat dirasakan.

Berbagai kerusuhan yang merupakan puncak dari konflik yang terjadi di lingkungan masyarakat adalah bagian dari penyebab sebuah ketidakteraturan dalam masyarakat. ${ }^{2}$ Kondisi yang demikian memang tidak mungkin untuk dipungkiri, karena hal ini adalah bagian dari proses pendewasaan suatu bangsa dan juga bagian dari proses pencapaian jati diri suatu bangsa. Hal yang terpenting dalam menghadapi situasi dan kondisi yang demikian adalah dengan cara mencari solusi yang terbaik, guna mencapai tujuan bersama bagi suatu bangsa.

Berangkat dari siutasi yang ada diatas maka munculah pertanyaan bagi kita semua, mengapa masyarakat yang beragama melakukan tindakan yang demikian? Padahal seharusnya masyarakat yang beragama adalah masyarakat yang mengaplikasikan keyakinan keagamaannya sehingga memunculkan ketenangan dan keteraturan dalam masyarakat. Secara tidak langsung maka dapat dipahami bahwa ini adalah sebuah kejadian yang patut untuk direnungkan untuk dicarikan jalan keluarnya.

Potensi permasalahan yang menyebabkan ketidakteraturan tersebut juga tentunya disebabkan oleh berbagai masalah lainnya, seperti politik, ${ }^{3}$ ekonomi, ${ }^{4}$

Konflik penyerangan terhadap jamaah ahmadiyah, terorisme, radikalisme, kasus ambon dll

2 Kerusakan pada sarana dan prasarana umum dari akibat adanya kerusuhan dan penyerangan antar anggota kelompok.

3 Banyaknya tokoh agama yang ikut dalam pentas politik diberbagai tempat mengakibatkan perpecahan umat atau jamaahnya,sehingga jamaahnya terpecah menjadi beberapa kelompok.

4 Perebutan sumber daya ekonoi yang mewarnai awal terpecahnya lembaga/pesantren besar yang ada di tanah air, misalnya pesantren yang berada di Blitar jawa timur, menjadi mengecil karena didalamnya terjadi perebutan tahta kepemimpinan. 
sosial, ${ }^{5}$ dan budaya. ${ }^{6}$ Pertarungan politik para pranata aturan dalam sebuah sistem yang menyebabkan ketidakteraturan diantaranya adalah perebutan kekuasaan sebagai konsekwensi dalam demokrasi. Persaingan ekonomi disebabkan karena perebutan potensi sumber daya ekonomi bagi seorang atau segolongan masyarakat tertentu, persaingan status sosial yang juga selalu muncul sejak waktu yang tidak sebentar. Sistem budaya yang berbeda yang juga sebagai penyebab terjadinya konflik yang menjadi salah satu sumber ketidakteraturan dalam masyarakat.

Uraian berikut akan mencoba menguraikan beberapa konflik dalam masyarakat yang mengakibatkan ketidakteraturan dalam masyarakat. Dengan mengetahui beberapa konflik yang terjadi tersebut diharapkan nantinya kita juga akan dapat mengetahui hal-hal yang menyebabkan terjadinya konflik dalam masyarakat. Dalam tulisan ini juga tentunya akan mengedepankan peran nyata para tokoh agama, baik agama islam, kristen, atau yang lainnya. Sehingga dengan peran inilah diharapkan konflik internal dan eksternal masyarakat akan dapat dikondisikan secara dinamis tanpa mematikan potensipotensi positif yang ada dalam kelompok masyarakat tertentu.

\section{B. Konflik Pemahaman Agama dan Politik Dalam Masyarakat}

Untuk memahami lebih dalam tentang agama dan politik alangkah baiknya kita sejenak memahami apa sesugguhnya esensi dari agama itu sendiri dan apa politik itu sendiri. Pada dasarnya pada kehidupan ajaran umat beragama memiliki ajaran untuk ketenagan, ketentraman, ketaatan, yang semua itu merujuk kepada hubungan manusia dan Tuhan dan juga merujuk kepada hubungan manusia dengan manusia dan juga lingkungan. Sedangkan politik adalah bagian yang tidak bisa dipisahkan dari dalam sebuah kelompok masyarakat. Sebetulnya politik adalah sebagian dari cara seseorang atau sekelompok manusia untuk mempengaruhi yang lainnya dalam rangka

\footnotetext{
Kecemburuan yang terjdi dalam masyarakat karena perbedaan tingkat sosial, misalnya adanya orang yang dianggap tokoh dan berpengaruh dalam masyarakat, akhirnya berusaha digulingkan ketokohannya.

6 Perbedaan budaya yang muncul dalam masyarakatyang disebabkan karena tingkat pendidikan dan lain-lain
} 
mencapai tujuan tertentu untuk "meningkatkan" budaya dan tradisi dalam masyarakat yang lebih baik ${ }^{7}$.

Dalam perkembangan modern pada saat ini agama selalu konsisten mengedepankan prinsip kehidupan yang yang selaras, serasi dan seimbang untuk meraih kebahagiaan dengan cara mengedepankan ketaatan terhadap hukum agama itu sendiri dan juga hukum suatu negara atau pemerintahan. Dalam kontek intern beragama di Indonesia terkait dengan kehiduan politik yang berkembang, pemahaman terhadap agama sering mengalami perubahan pemahaman, yang mana pemahaman tersebut berangkat dari pemahaman yang dipahamkan oleh seorang tokoh agama, yang mana tokoh agama tersebut memiliki tujuan tertentu untuk mencapai tujuannya. Pemahaman yang ditanamkan oleh tokoh agama dalam masyarakat pada hakekatnya adalah sebuah cara yang digunakan untuk mendapatkan dukungan misalnya, atau mendapatkan rasa simpati dalam sebuah komunitas masyarakat. Dengan demikian maka disini peran agama adalah sebagai alat komunikasi politik bagi para tokoh agama untuk mendapatkan dukungan dari para pengikutnya. ${ }^{8} \mathrm{Hal}$ yang demikian dapat dikatan agama sebagai alat politik.

Lain halnya dengan politik yang beragama. Jika anggapan ini muncul dari segolongan masyarakat yang berpahaman bahwa agama tidak boleh digunakan sebagai sarana politik sehingga menurutnya agama adalah sebuah alat untuk mengendalikan sistem politik yang cenderung negatif. Misalnya adalah polotik yang menghalalkan segala macam cara. Jika agama sebagai sarana politik maka hal tersebut adalah termasuk bagian dari menghalalkan berbagai cara. Lain halnya dengan agama sebagai pengendali, yaitu jika agama dijadikan norma dasar dalam berpolitik sehingga terjauhkanlah politik dari kecurangan-kecurangan yang muncul dari sifat manusia.

Dalam hal hubungan antar umat beragama juga mengalami hal yang demikian. Banyak sekelompok orang yang memanfaatkan kelompok agamanya untuk mendapatkan tujuannya. Sehingga para tokoh masyarakat dalam kelompok tersebut memberikan pemahaman yang diarahkan untuk

7 Robert W. Hafner. Introduction, Society and Morality in the New Asian Capitalism" dalam Robert w. Hafner, ed., Market Cultures: Sosiety and Morality in the New Asian Capitalism,(Boulder: Westview, 1998). 1-38

8 Zaenah Anwar, Islamic Revivalism in Malaysia: Dakwah Among tha Students. (Petaling Jaya, Pelanduk: 1987). 41-42 
mendapatkan dukungan tanpa melihat situasi dan kondisi yang sedang terjadi dalam masyarakat. Misalnya banyak tokoh politik yang menggunakan orasi keagamaan dan memandang salah idiologi yang lainnya. Dengan demikian maka hal ini juga akan menjadi penyebab konflik antar kelompok agama dalam masyarakt.

Jika dalam sebuah kelompok masyarakat terjadi "kecurangan," maka hal ini sangat memungkinkan akan terjadinya konflik, yang mana konflik ini akan memicu ketidakteraturan dalam masyarakat. Konflik yang muncul dari pemahaman agama sebagai alat politik misalnya adalah akan memicu terpecahnya segolongan masyarakat sehingga diantara mereka akan saling menyalahkan dan beranggapan bahwa dirinyalah yang paling benar dan menyalahkan golongan yang lain. Hal tersebut berangkat dari pemahaman bahwa politik adalah boleh melakukan apa saja untuk meraih tujuan yang ingin dicapai.

Dalam situasi yang demikian selanjutnya para tokoh agama akan saling membentuk pemahaman dan juga menentukan titik keseimbangan pemahaman tentang politik dan situasi yang terjadi untuk mewujudkan kondisi yang tidak semakin keruh. Hal demikian juga tidak dapat dinafikan bahwa pemahaman yang demikian adalah hal yang akan selalu muncul sesuai dengan perkembangan masa politik dan modernisasi. ${ }^{9}$

\section{Ekstrimisme dan "Kemlencengan" Idiologi}

Agama dalam masyarakat modernisitas pada saat sekarang ini nampaknya mengalami tantangan yang serius. Berangkat dari tantangan intern agama itu sendiri smpai pada tantangan ekstern dengan agama lain. Tantangan intern yang dihahadapi dengan agama itu sendiri diantaranya adalah tantangan dalam memahamkan kepada penganutnya tetang ajaran agama yang seluasluasnya untuk dipahami dan diaplikasikan dalam kehidupan, sehingga hal tersebut akan meminimalisir konflik intern agama yang disebabkan karena keterbatasan pemahaman yang dimiliki oleh penganutnya. Tantangan agama yang lebih luas adalah dalam mengahadapi posisi agama bagi masyarakat modernis saat sekarang ini. Banyak hal yang harus dijelaskan sesuai dengan

9 Fathi Osman, Sharia in Contempory Society: The Dynamics of Change in Islamic Low. (Los Angels, Multimedia Vera Internasional: 1994). 
tingkat perkembangan kemoderenan masyarakatnya sehingga agama dapat dengan mudah diterima oleh berbagai pihak, baik yang seagama maupun yang tidak seagama.

Yang terjadi pada saat sekarang ini tentang agama paling tidak ada dua macam. Pertama masyarakat memahami agama sebagai sesuatu yang mudah, kedua masyaaat beranggapan bahwa agama adalah sesuatu yang sulit karena ajarannya sukar untuk diaplikasikan pada waktu sekarang ini. Masyarakat yang beranggapan bahwa agama adalah sesuatu yang mudah adalah masyarakat yang memiliki tingkat pemahaman agama yang masih "pemula". Dalam hal ini masyarakat sering mengedepankan esensi dari ajaran agama itu sendiri sehinga meninggalkan ritual ajaran agama, misalnya pemahaman yang demikian dalam agama islam adalah masyarakat yang beranggapan mendirikan sholat seperti ajaran para Rosul adalah tidak perlu, namun cukup dengan ingat kepada Tuhan saja sebagai esensi dari ajaran sholat itu sendiri.

Pemahaman masyarakat tentang agama yang sulit untuk diaplikasikan adalah salah satu tantangan yang juga besar, karena pemahaman yang demikian adalah beranggapan bahwa ajaran agama adalah sesuatu yang mutlak seperti apa yang diajarkan tanpa harus melihat penyebab turunnya suatu ajaran dalam sebuah agama. Dalam ajaran kristen perbedaan pemahaman yang demikian menyebabkan perpecahan, sehingga kristen terpecah menjadi dua, yaitu Katolik dan Protestan. Dalam lingkup yang lebih kecil yang terjadi dimasyarakat kristen juga masih terbagi lagi menjadi kristen jawa dan lain sebagainya.

Hal tersebut sebagai konsekwensi dari adanya pemahaman agama yang sempit sehingga masyarakat yang memiliki pemahaman tersebut cenderung extreme dan sempit sehingga merasa sulit untuk mengamalkan ajaran agamanya. Dalam proses aplikasi ajaran agama dimasyarakat, banyak masyarakat yang harus melakukan penolakan tehadap sesuatu yang ada disekitarnya, misalnya saja dalam ajaran islam banyak yang selalu dan selalu melakukan penolakan terhadap perbedaan pemahaman idiologi keagamaan. Sehingga dengan perbedaan pemahaman itu mengakibatkan konflik dalam masyarakat. misalnya saja dalam islam berakibat terpecahnya islam menjadi beberapa nama, ada Muhamadiyah, NU, LDII, MTA, Salafiyah dan lain sebagainya, yang masingmasing mengklaim dirinya yang benar. Sehingga terjadi proses pem-bid'ah- 
an,peng-khurafat-an, dan peny-syirik-an yang dilakukan oleh masing-masing organisasi pada ranah penggerak aliran pemurnian idiologi agama..$^{10}$

Dari perbedaan nama yang diakibatkan dari perbedaan pemahaman atau perbedaan idiologi dalam sebuah masyarakan juga sangat memicu terjadinya konflik dalam sebuah kelompok masyarakat. Dalam konteks eksternal agama, juga diwilayah-wilayah tertentu di Indonesia terjadi penolakan terhadap berkembangan ajaran agama lain di daerahnya.

Hal tersebut seharusnya dalam masyarakat yang sudah meyakini agama tidak harus tejadi, karena dalam ajaran agama mereka, agama apa pun yang mereka anut, tentunya adalah mengedepankan ajaran tentang holistisitas sebuah kehidupan di dunia untuk mencapai tujuan kebahagiaan di akherat. Keholistisan ajaran agama tersebut tentunya adalah dengan cara memahami aspek sosial yang masih berkembang dalam masyarakat, sehingga dapat membuka mata pemahaman yang tertutup dengan keekstriman yang sempit dalam masyakat, yaitu dengan cara menghilangkan syarat "tidak boleh adanya penyimpangan dalam syariat Islam dan membedakan secara ketat antara mereka yang beriman dengan orang yang tidak beriman." 11

\section{Pemahaman Agama dalam Masyarakat}

Agama adalah sebuah ajaran ayang diturunkan oleh Tuhan melalui malaikat dan rosulNYa yang bertujuan untuk menata kehidupan umat manusia. Hal itu adalah salah satu esensi dari tujuan diturunkannya agama kemuka bumi ini. Hal ini tidak banyak dipahami oleh banyak umat manusia yang beragama, kebanyakan dari umat manusia yang beragama memahami ajaran agama hanya sebatas untuk kehidupan diakherat saja, sehingga yang terjadi adalah pemahaman agama yang tidak utuh dan malah terkadang jauh dari tujuan agama itu sendiri.

Banyak kalangan agamawan yang memberi pemahaman bahwa agama adalah sesuatu yang harus jauh dengan dunia ini, padahal adanya ajaran agama diturunkan kemuka bumi ini adalah karena adanya dunia, dan dengan demikian tentunya agama tidak bisa dipisahkan dari dunia ini. Pandangan tersebut

10 . K. Yudian Wahyudi, Gerakan Wahabi di Indonesia, (Yogyakarta, Bina Harfa, 2009), Hlm. 4

11 JohnO. Voll,Islam: Continuity and Change in the Modern World,cet. 2 (Syaracuse, NY: Syracuse University Press, 1994), Hlm. 53-56 
beranggapan bahwa ajaran agama bagi manusia adalah sesuatu yang harus djauhkan dari segala apa yang ada di dunia ini, sehingga manusia akan dapat mengaplikasikan ajaran agama dengan baik. Dalam ajaran agama budha, hal ini disebut dengan ajaran "moksa", sedangkan dalam ajaran islam hal tersebut adah ajaran "zuhud". Yang perlu dipertanyakan apakan betul pemahaman tentang moksa dan zuhud itu demikian seperti yang sudah dipahami, harus lari dari dunia ini? Hal tersebut tentunya perlu direnungkan dan diluruskan agar para penganut agama dapat memahami degan benar dan mudah untuk diaplikasikan dengan mudah, apalagi terkait dengan modernisitas kehidupan yang salalu berjalan dan tidak akan mungking untuk berhenti ini.

Sebagaian masyarakat juga beranggapan bahwa agama adalah hanya apa yang tertera dalam kitab sucinya saja. Sehingga bagi para penganut pemahaman ini memiliki pemahaman yang begitu sempit. Pemahaman yang demikian menjadikan mereka tidak mudah bergaul dengan sesama hidup karena berdalih menjalankan ajaran suatu agama. Hati dan dunia mereka menjadi sempit, seakan agama adalah seperangkat alat pemersempit ruang gerak manusia. Pemahaman-pemahaman yang demikian seyogyanya juga mendapatkan pencerahan agar mereka terlepas dari belenggu pemahaman mereka sendiri yang sempit yang dakibatkan dari pemahaman agama yang diyakininya.

Lain halnya dengan masyarakat yang tidak terlalu mengedepankan tentang agama, mereka hidup dengan berjalan apa adanya dan apa maunya, seolah hidup ini tidak akan ada pertengungjawaban dihari nanti kelak. Mereka menganggap agama sebagai sebuah permainan yang "tabu" untuk dipercaya apa lagi diyakini. Akibat dari banyaknya pemahaman tentang ajaran agama yang berkembang dalam masyarakat, akan memunculkan banyak pandangan, sehingga seolah-olah agama adalah penyebab dari konflik dan ketidakteraturan. Pemahaman yang demikian muncul dari masyarakat yang terbalik dan meragukan akan kebenaran ajaran agama yang ada disekitarnya (ateisme)

Akibat lain dari pemahaman yang seperti demikian ini adalah terperangkapnya masyarakat dalam sebuah kelompok masyarakat yang kaku dan ekstreme, sehingga mereka akan sulit untuk menerima apa yang ada disekitarnya sebagai bentuk konsekwensi kehidupan di dunia ini. Kesulitan penerimaan yang dialami ini akan mengarah kepada penolakan-penolakan 
terhadap sesuatu atau kelompok lain yang juga berakibat kepada konflik yang menjurus kepada ketidakteraturan dalam kelompok masyarakat.

\section{E. Pendidikan Keagamaan dalam Masyarakat}

Seiring dengan kemajuan zaman yang ada pada saat sekarang ini, manusia berlomba untuk menjadi yang terbaik dan tercepat. Salah satu jalan yang ditempuhnya adalah dengan jalur pendidikan. Pada awalnya muncul pendidikan di Indonesia adalah dengan sistem klasikal yang hanya bermuatan pendidikan keagamaan dan moral saja. Hal ini dapat diketahui dengan menengok sejenak kepada sejarah munculnya pendidikan di Indonesia.

Diawali dari masuknya agama-agama di Indonesia melalui bentuk kepemimpinan kerajaan, yaitu diawali dari agama Hindu dan Budha, kemudian disusul oleh masuknya islam ke nusantara, dan juga kristen. ${ }^{12}$ Semua agama itu masuk melalui peran para pedagang yang melakukan bisnis di Indonesia (yang waktu itu Indonesia masih dalam bentuk kerajaan). Mereka melakukan bisnis dan perdagangan dengan dobel misi, yaitu mencari keuntungan dengan barang dagangannya dan juga melakukan ekspansi dakwah keagamaannya.

Sistem pendidikan yang dilakukan pada waktu itu tidak menggunakan kelas seperti yang ada pada saat sekarang ini, namun mereka memasukan nilai-nilai keagamaan yang mereka yakini itu melalui kemuliaaan akhlak yang di milikinya, yang diwujudkan dalam amal kehidupan. Hal ini dilakukan oleh penganut agama Hindu dan Budha yang masuk ke wilayah Indonesia. Dengan kelembutan dan keramahan akhlak yang dimilikinya itu, masyarakat mulai tertarik dan berkeinginan belajar lebih mendalam tentang apa yang dihadapinya itu, yaitu sebuah keyakinan beragama (Hindu dan Budha). ${ }^{13}$ Demikian sederhananya cara para pembawa agama dalam mendakwahkan ajaran agamanya sehingga mudah diterima oleh masyarakat yang sebelumnya masih berkeyakinan anemisme dan dinamisme, yang kemudian membawa mereka meyakini suatu ajaran agama.

Lain halnya dengan para pembawa ajaran islam yang masuk ke Indonesia. Mereka juga seorang pedagang yang juga tentunya memiliki dobel misi dalam

\footnotetext{
12 Dojosantoso: unsur religius dalam sastra jawa, (Semarang, Aneka Ilmu:1985) hlm.5-16

13 Ibid Dojosantoso: unsur religius.....
} 
perjalanannya, yaitu dagang dan mencari keuntungan. Dengan kejeliannya menghadapi masyarakat Indonesia yang bercorak Hindu dan Budha, para pembawa ajaran islam ke Indonesia, mereka melakukan revolusi ajaran dan juga sistem pembelajaran ajaran agamanya kepada masyarakat. Revolusi yang dilakukan adalah dengan tujuan mendapatkan posisi yang tepat dihati masyarakat yang sudah memiliki agama dan keyakinan. Dengan posisi tersebut ajaran islam mendapatkan tempat dalam hati para pemeluk agama tertentu, yang akhirnya sedikit demi sedikit ajaran islam dapat diterima oleh masyarakat dan akhirnya diyakininya juga. Ketika kita melihat betapa berbedanya bentuk ajaran islam yang dibawa oleh Rosul dan bentuk ajaran islam yang dibawa oleh para saudagar (termasuk wali songo). Para rosul mendakwahkan ajaran islam dengan langsung kepada masyarakat yang hanya mengedepankan akhlak dan budi pekerti. Sedangkan para ulama islam yang datang ke Indonesia harus menyesuaikan bahasa, kultur budaya, bahkan sistemnya, tidak hanya menggunakan akhlak dan budi pekerti namun juga dengan modifikasi ajarannya. Seperti misalnya budaya gending yang hanya ada di pulau jawa, hal ini dijadikan alat berdakwah yang dipadukan dengan seni pewayangan yang ceritanya diadopsi dari India dan disesuaikan dengan ajaran islam. Rosululloh tidak melakukan modifikasi tersebut, namun para ulama tanah jawa berijtihad melakukan itu sebagai bentuk revolusi dalam sistem pendidikan agama terhadap masyarakat.

Berbeda ajaran agama, tentunya berbeda pula cara dalam berdakwahnya, begitu pula yang dilakukan oleh kaum Kristiani. Kristen dibawa masuk ke Indonesia oleh Belanda, mereka tidak hanya berekspansi mencari sumber daya alam yang ada di Indonesia, namuan juga membawa dan menyebarkan ajaran kristen ke Indonesia. Dengan kejeliannya pula Belanda menggunakan triknya. Karena mereka telah melihat kemajemukan masyarakat Indonesia dalam bidang agama dan budaya akhirnya mereka membuat semacam pengembangan untuk penyesuaian. Para penganut kristen di Indonesia juga melakukan dakwah dengan akhlak dan budi pekerti, budaya gending jawa dan pewayangan. Yang lain dengan pembawa agama sebelumnya Belanda menggunakan tandingan. Hal ini dilakukan oleh tokoh kristen yang berada diwilayah Purworejo bagian barat daya yaitu "Kiyai Sadrach". dia menggunakan prinsip bahwa islam bisa diterima oleh masyarakat jawa dengan cara yang "sakti" atau yang msitis. Sehingga dia berpikiran bahwa Kristen juga demikian, sehingga dia melakukan 
hal tersebut untuk dapat mengambil hati masyarakat untuk mengikuti dan meyakini ajarannya.

Demikian banyaknya metode yang digunakan para tokoh pembawa keagamaan masuk ke Indonesia. Hal ini dapat diambil manfaat bagi kita sebagai generasi penerus yang ada di Indonesia untuk melakukan ekspansi dan perjalanan dalam rangka menegakan esensi dari ajaran agama yang ada dan yang di yakini dalam masyarakat. Selanjutnya dapat menilai kebenaran ajaran yang disampaikan oleh pembawanya dengan benar untuk dapat diyakini dan di aplikasikan dalam hidup, tidak sekedar yakin namun juga harus dengan penuh pertanyaan yang dimunculkan, baik bagi penganutnya maupun penganut yang lainnya.

Esensi dari semua ajaran agama yang ditanamkan dan dikembangkan adalah bertujuan untuk mencapai sebuah keteraturan dalam kehidupan di dunia. Sebuah ketidaktenangan yang muncul dari hati seseorang akan memunculkan pandangan bagi dirinya yang kemudian disampaikan kepada orang lain, orang lain juga akan memiliki pertanyaan yang senada dan akan menjadi kelompok dalam mayarakat yang memiliki kesamaan pandangan dan akan mempertanyakan kepada kelompok lain. Jika kelompok lain bisa menerima dan menjawabnya maka akan memberikan penjelasan bagi kelompok penanya terkait dengan pandangan idiologinya, jika pandangan jawabannya itu sama dengan pandangan kelompoknya maka kelompok itu akan merasa menjadi bagian dari kelompok lain, namun jika pendangan atas jawaban pertanyaannya itu berlainan maka justru akan menjadi pemicu konflik yang mengarah kepada ketidakteraturan dalam hal pandangan dan idiologi keagamaan.

Itulah sebabnya mengapa dalam memahami dan menyampaikan suatu ajaran agama harus memperhatian banyak aspek yang berkembang dalam masyarakat. Baik dari aspek sosial, ekonomi, budaya, politik, pendidikan, dan aspek yang lainnya. Dengan demikian maka akan tercapailah pandangan dan pemahaman yang luas akan ajaran suatu agama, dan kefleksibelan dalam memandang ajaran agama, yang pada tujuannya dapat mebawa kepada keteraturan dalam kehidupan manusia. 


\section{F. Kontruksi Peran Tokoh Masyarakat Terhadap Pemahaman Suatu Agama}

Dalam sebuah komunitas, baik komunitas formal maupun non formal kemasyarakatan, disadari atau tidak pasti ada yang disebut dan berperan sebagai tokoh. makna tokoh dalam konteks ini adalah orang yang memiliki peran dan memiliki pengaruh terhadap orang-orang disekitarnya. Sebagai contohnya dalam komunitas formal disekolah, pasti ada seorang pemimpin (kepala sekolah), yang mana pemimpin disekolah ini akan berperan memberi warna, arah, dan menentukan tujuan yang akan dicapai, melalui kerjasama dengan orang-orang yang ada dalam suatu sekolah. Sedangkan suatu contoh dalam komunitas non formal, misalnya saja pada komunitas remaja yang melakukan touring kesuatu tempat mereka akan menganggap seseorang sebagi leadernya untuk menentukan rute perjalanan yang akan ditempuhnya.

Begitu pula hal ini terjadi dalam suatu kelompok masyarakat, siapa yang menjadi pemimpin dalam masyarakat maka dia akan menjadi salah satu pusat titik perhatian. Dengan perhatiannya tersebut maka masyarakata atau orang-orang disekitarnya sedikit demi sedikit akan terpengaruh oleh apa yang dilakuannya. Misalnya saja dari cara bicaranya, cara berpakaian, bahkan cara berjalannya. Hal ini dalam konteks psikologis disebut sebagai bentuk imitasi seseorang terhadap orang lain. Hal ini tidak mudah untuk dipungkiri dalam suatu kelompok masyarakat.

Terkait dengan pemahaman suatu ajaran agama pada masyarakat, peran tokoh masyarakat dalam memberi pemahaman suatu agama tentunya sangat memberi pengaruh. Bagi tokoh masyarakat yang memiliki tingkat pemahaman suatu agama yang sederajat dengan lingkungannya, maka kemungkinan dia tidak terlalu banyak memberikan pengaruh dalam hal idiologi keagamaan (berpengaruh namun hanya sedikit) Bagi tokoh masyarakat yang memiliki pemahaman sedikit atau sederajat dengan orang-orang disekitarnya tentang idiologi suatu agama, maka dia akan cenderung memiliki pengaruh bukan karena idiologi keagamaannya, namun tentunya karena kelebihan dibidang yang lainnya. Dengan demikian maka dapat dikatakan bahwa tokoh masyarakat yang hanya sedikit dalam memahami idiologi suatu agama maka dia akan tidak banyak memberi kontribusi dalam bidang pemahaman terhadap suatu keagamaan (artinya dapat dikatakan memiliki peran negatif terhadap 
pemahaman suatu agama kepada lingkungannya, karena tidak berkontribusi langsung untuk memberi pemahaman, dan juga aplikasi suatu ajaran agama terhadap masyarakat). Sedangkan bagi tokoh masyarakat yang memiliki pemahaman suatu agama dengan lebih baik dibandingkan orang-orang lain disekitarnya, maka dia akan dapat secara langsung memberikan pemahaman, contoh atau aplikasi suatu ajaran agama terhadap orang-orang disekitarnya. (maka tokoh ini memiliki peran postitif terhadap suatu ajaran agama).

Pernyataan ini memberikan gambaran bahwa seorang tokoh masyarakat memiliki peran yang sangat setratgis dalam memberikan suatu pemahaman agama terhadap masyarakat sekitarnya. Hal ini jelas terjadi dalam lingkungan masyarakat yang selalu mengalami proses modernisasi seperti saat sekarang ini. Tokoh masyarakat memiliki peran dalam memberikan balancing atau keseimbangan didalam masyarakat untuk dapat memahami sesuatu dengan baik dan dapat bermanfaat bagi dirinya dan lingkungan, sesuai dengan perkembangan dilingkungannya. ${ }^{14}$

Tokoh masyarakat bukanlah hanya sebuah simbul bagi kelompok formal masyarakat, atau sebuah panutan yang akan membawa kearah yang tidak jelas bagi kelompok non formal dalam masyarakat. Lebih dari itu, tokoh masyarakat adalah memiliki peran strategis, peran praktis, peran edukatif, dan peran psikis, sehingga tokoh masyarakat bisa menjadi sang penolong dalam kesusahan, sang pencerah dalam kegelapan, sang guru dalam kebodohan, sang penyejuk dalam kepanasan. Artinya juga bahwa tokoh masyarakat adalah pemain sentral dalam suatu kelompok masyarakat yang pandai dalam melakukan kerjasama, menentukan langkah dan lain sebagainya terkait dirinya dan juga lingkungan sekitarnya.

Hal ini sangat perlu untuk dikedepankan dalam masyarakat yang ada pada saat sekarang ini, karena tokoh masyarakat yang ada pada saat ini adalah baru sebatas simbul dalam kelompok formal masyarakat, dan baru sebatas idola dalam kelompok non formal masyarakat. Sebatas simbul dalam kelompok masyarakat formal, karena tokoh hanya menjalankan apa yang sudah ada dan belum melakukan tugasnya dengan baik sehingga pemahaman suatu keagamaannya muncul dan dapat dilihat, serta dapat ditiru oleh masyarakat disekitarnya. Sedangkan tokoh masyarakat yang hanya sebatas idola, karena

${ }_{14}$ Chris Barer: Cultural Studies, (Yogyakarta: Kreasi wacana, 2004) Hlm. V-IX 
para tokoh masyarakat hanya diidolakan saja, tidak banyak mewarnai dan mengedepankan ajaran suatu keagamaan yang dapat membawa kearah pemahaman suatu ibadah terhadp idiologi suatu agama dengan baik dan lebih luas.

\section{G. Kontruksi Peran Tokoh Agama dalam Memberi Pemahaman Masyarakat Terhadap Agama Menuju Suatu Keteraturan Hidup}

Dalam hal ini tokoh agama dibedakan dengan tokoh masyarakat, yang dimaksud dengan tokoh agama disini adalah seprti kiyai/ustadz, pendeta, biksu dan yang setingkatnya. Sehingga jelas siapa yang dimaksud sebagai tokoh agama. Hal ini perlu dibedakan karena tokoh masyarakat belum tentu menjadi tokoh agama, dan tokoh agama juga belum tentu sebagai tokoh masyarakat, walaupun sebagaian besar tokoh agama dijadikan tokoh masyarakat.

Fenomena yang terjadi dan banyak dirasakan oleh masyarakat adalah suasana yang tidak teratur. Hal tersebut ditunjukan dengan indikasi perubahan sesuatu yang ada, misalnya sistem pendidikan yang berubah (dilihat dari kurikulumnya), cuaca yang berubah, pertambahan penduduk yang berubah dan bertambah padat dalam suatu wilayah. Hal itu membutuhkan suatu penyesuaian, dalam proses penyesuaian terhadap sesuatu tentunya mengakibatkan suatu perubahan, dan perubahan itu tidak jarang mengarah kepada ketidakteraruran (baik bagi diri sendiri maupun lingkungan), bahkan sering juga mengarah kepada konflik.

Agama adalah suatu ajaran yang diyakini dan amalkan yang memiliki tujuan unifersal untuk keteraturan dunia dan seisinya termasuk manusia didalamya. Artinya bahwa jika suatu agama hanya dipahami sebagian saja dan hanya sebagai kegiatan formalitas dihadapan Tuhan dan manusia, maka tujuan dan peran agama yang secara unifersal akan tidak tercapai. Mengapa demikian? Agama yang dipahami hanya sebagian saja, maka ajaran agama hanya akan memunculkan kemunginan-kemungkinan baru dan penafsiran baru yang tidak mengarahkan kepada kemaslakhatan/keteraturan dunia seisinya ini. Sebagai contoh, behwa dalam kitab suci disebutkan manusia untuk menggunakan potensi alam demi kesjahteraan manusia. Jika hanya satu perintah tersebut yang dipahami dan diamalkan, maka akan terjadi eksploitasi besar-besaran dan akhirnya justru akan merusak lingkungan dan melahirkan 
ketidakteraturan alam ini. Selanjutnya jika ajaran agama hanya dipahami sebagaian saja maka juga akan melahirkan kemungkinan dan penafsiran baru yang membawa kepada perbedaan idiologi dan melahirkan madzhab baru dalam suatu agama.

Terkait dengan hal tersebut, maka peran tokoh suatu agama dalam suatu masyarakat adalah sangat diperlukan dalam rangka mncapai tujuan universal suatu agama itu sendiri. Berbagai langkah yang dilakukan oleh tokoh agama dalam memberikan pemahaman suatu agama sehingga dapat dengan mudah dipahami dan diaplikasikan oleh lapisan masyarakat. Ketika kita menengok kisah wali songo dalam islam mereka melakukan pemahaman dengan metode akulturasi budaya dan agama sehingga nilai-nilai agama yang dipandang kurang dipahami dan diaplikasikan dalam hidup masyarakat, akhirnya dapat diterima, dipahami dan diaplikasikan. Dalam ajaran tokoh agama Hindhu Budha, mereka mengedepankan keseimbangan hidup manusia dengan alam sehingga menghasilkan suatu keteraturan dalam ekosistem alam dan kehidupan manusia. Dalam ajaran kristiani, para tokohnya mengedepankan nilai-nilai kasih sayang kepada sesama. Dengan demikian maka agama yang ada dalam suatu masyarakat akan saling melengkapi dan mengarah kepada keteraturan lingkungan, sosial, dan alam.

Terkait dengan perkembangan masa modernisasi, karena manusia dituntut utuk selalu dan selalu cepat dalam menghadapi lingkungan dan juga mimiliki fungsi bagi lingkungan, maka masing-masing tokoh agama berupaya untuk mengedepankan nilai-nilai behafior atau pendidikan. ${ }^{15} \mathrm{Hal}$ tersebut dilakukan dengan mendirikan lembaga pendidikan baik formal maupun non formal, bahkan informal. Tidak hanya itu, terkait dengan modernisasi dan tuntutan zaman tidak sedikit lembaga pendidikan yang didirikan oleh suatu agama tertentu dan melakukan metamorfosis sehingga mereka akan tetap relefan dengan lingkungan masyarakatnya. Metamorfosisi itu dapat ditemukan hampir disemua agama yang ada, dalam islam melakukan metamorfosis dari sistem pendidikan salafi bermetamorfosis menjadi sistem pendidikan modern dan juga perpaduan salaf dan modern, yang terfokus kepada kurikulum pembelajaran dan sistem pembelajarannya. Misalnya yang dulu hanya bermuatan agama, namun sekaran diisi dengan muatan

15 Ibid Chris Barer: Cultural...... Hlm 8-9 
ketrampilan hidup. Sedangkan dalam agama kristen, sistem pendidikan yang dahulunya bermuatan umum dan keagamaan dengan sistem pendidikan klasikal, kemudian bermetamorfosis menjadi sistem asrama.

Disinilah peran para tokoh agama dalam memberikan pemahaman suatu agama terhadap masyarakat. Mereka melakukan tindakan berupa pembelajaran dimasyarakat dalam bidang pendidikan, ekonomi (dengan cara memotifasi semangat kerja), budaya (dengan cara memodifikasi dan menumbuhkan budaya baru), bahkan politik (dengan memasuki dunia politik untuk meluruskan ajaran suatu agama), sampai pada merambah pada sistem pertahanan dan keamanaan suatu negara (dengan cara membentuk gerakan pemuda/banser dalam organisasi islam). Inilah peran besar yang nyata dalam masyarakat yang dilakukan oleh para tokoh keagamaan.

\section{H. Sinergi Tokoh Agama dengan Perkembangan Lingkungan Masyarakat}

Sebagaimana yang telah dibahas pada bagian sebelumnya bahwa tokoh agama memiliki peran yang sentral dalam rangka memberikan pemahaman suatu agama dalam rangka menuju keteraturan masyarakat dalam berbagai bidang kehidupan. Berangkat dari asumsi itulah maka muncul pemahaman bahwa dalam rangka mewujudkan masyarakat yang teratur tentunya tokoh agama juga selalu melakukan sinergi dengan lingkungan dimana mereka berada. Apa saja bentuk-bentuk sinergi yang dilakukan oleh para tokoh agama akan dibahas sebagai berikut.

Ibarat sebuah makhluk dalam suatu ekosistem, untuk dapat berhasil menjalani kehidupannya, mereka harus melakukan adaptasi dengan lingkungan dan anggota ekosistem yang ada. Tidak boleh mereka melakukan resistensi sistem kehidupan secara frontal, karena akan berakibat fatal bahkan memusnahkan dirinya, bahkan juga dapat memusnahkan ekosistemnya, karena akan termakan oleh kerasnya kehidupan dilingkungan yang tercipta itu. inilah ibarat dari pentingnya sebuah sinergi yang dilakukan oleh para tokoh agama.

Esensi pemahaman tentang sinergi disini adalah sebuah penyesuaian yang dilakukan oleh tokoh agama dengan lingkungannya dalam rangka untuk 
mencapai tujuan universal suatu agama, yaitu lingkungan dunia yang teratur. Dalam rangka mencapai tujuan tersebut para tokoh agama melakukan proses perjalanan penysusupan kedalam sendi kehidupan masyarakat yang sangat panjang dan terjal. ${ }^{16}$ Mengapa demikian, karena seperti digambarkan diatas, jika salah dalam melangkah maka hal tersebut akan berakibat fatal, sehingga mereka harus melakukan perjalanan dengan penuh kehati-hatian, mengena kepada sasaran/tepat, dan bermanfaat. strategi yang dilakukan dalam komunitas masyarakat jawa hal yang demikian disebut dengan istilah ngeli tapi ora keli yang artinya menghanyutkan diri namun tidak kandas terhanyut. itulah salah satu cara yang dilakukan agar para tokoh agama tidak mendapatkan resistensi dari masyarakat dilingkungannya.

Tujuan dari sinergi yang dilakukan ini adalah untuk menanamkan nilainilai agama yang mereka yakini kepada masyarakat, yang selanjutnya dapat diamalkan dan dapat menghasilkan suatu tatanan masyarakat yang teratur. Di era yang serba canggih ini, banyak tokoh masyarakat yang senantiasa melakukan sinergi melalui bidang pendidikan, mereka mengawali dari dirinya sendiri, dengan cara melanjutkan pada pendidikan yang lebih tinggi, mendirikan lembaga pendidikan, sehingga para tokoh agama dan pengikutnya tidak gagap teknologi. Dibidang ekonomi mereka melakukan sinergi dengan banyak melakukan lobi-lobi kepada pengusaha agar dirinya dan kelompoknya dapat melakukan suatu bisnis yang menguntungkan, seperti misalnya bekerjasama dengan bank untuk peminjaman modal usaha, bahkan juga mendirikan bank syariah sendiri. Dalam bidang politik, dengan terbukanya pintu demokrasi di belahan dunia, banyak para tokoh agama yang menduduki posisi strategis dalam pemerintahan, sehingga dengan mudah membuat kebijakan yang bernilai religi baginya dan masyarakat.

Dalam kontek keagamaan, dengan beragamnya agama yang berkembang dibelahan dunia ini, para tokoh agama juga selalu melakukan sinergi dengan cara melakukan musyawarah dan bekerjasama untuk menjaga kedamaian diantara umat beragama. Dalam kontek kesinergian ini, maka tersisihlah bagi tokoh agama yang tidak mau bahkan menolak terhadap sesuatu yang ada disekitarnya, karena hal itu adalah sebagai salah satu penolakan terhadap proses sinerginisasi yang harus dilakukan.

16 Nur Efendi, Islamic Educational Leadership (Yogyakarta: Parama Publishing, 2015) Hlm.222-226 


\section{Kesimpulan}

Dari apa yang telah diuraikan diatas maka dapat dipahami, bahwa tokoh agama memiliki posisi yang strategis dalam suatu masyarakat untuk mengarahkan masayarakat menuju sebuah keteraturan sosial. Tokoh agama dapat dikatakan sebagai tokoh masyarakat yang positif dalam pemahaman keagamaan, karena mereka dapat memberi pemahaman tentang suatu ajaran agama kepada masyarakat melalui amal hidupnya dan juga cara masing-masing yang dilakukan. Peran tokoh agama yang lebih konkret dalam masyarakat untuk mewujudkan keteraturan adalah adanya sistem pendidikan yang dilakukan, dengan selalu melakukan penyesuaian terhadap perkembangan zaman (metamorfosis sistem pendidikan). Selain itu para tokoh agama juga melakukan sinergi terhadap perkembangan lingkungan untuk mewujudkan tujuan universal agama, yaitu keteraturan sosial kehidupan di dunia.

\section{DAFTAR PUSTAKA}

Anwar, Zaenah, Islamic Revivalism in Malaysia: Dakwah Among tha Students. (Petaling Jaya, Pelanduk: 1987)

Chris Barer: Cultural Studies, (Yogyakarta: Kreasi wacana, 2004)

Hafner, Robert W. Introduction, Society and Morality in the New Asian Capitalism" dalam Robert w. Hafner, ed., Market Cultures: Sosiety and Morality in the New Asian Capitalism,(Boulder: Westview, 1998).

John O. Voll,Islam: Continuity and Change in the Modern World,cet. 2 (Syaracuse, NY: Syracuse University Press, 1994)

Nur Efendi, Islamic Educational Leadership (Yogyakarta: Parama Publishing, 2015)

Osman, Fatih, Sharia in Contempory Society: The Dynamics of Change in Islamic Low. (Los Angels, Multimedia Vera Internasional: 1994).

Wahyudi, K. Yudian, Gerakan Wahabi di Indonesia, (Yogyakarta, Bina Harfa, 2009). 